Article

\title{
Universities and Wineries: Supporting Sustainable Development in Disadvantaged Rural Areas
}

\author{
Chiara Aleffi ${ }^{1, *(\mathbb{D}}$, Sabrina Tomasi ${ }^{1, *(\mathbb{D}}$, Concetta Ferrara ${ }^{1}{ }^{(\mathbb{C}}$, Cristina Santini ${ }^{2}$, \\ Gigliola Paviotti ${ }^{1}$ D, Federica Baldoni ${ }^{1}$ and Alessio Cavicchi ${ }^{1}$ (D) \\ 1 Department of Education, Cultural Heritage and Tourism, University of Macerata, 62100 Macerata, Italy; \\ c.ferrara3@unimc.it (C.F.); gigliola.paviotti@unimc.it (G.P.); f.baldoni7@unimc.it (F.B.); \\ alessio.cavicchi@unimc.it (A.C.) \\ 2 Faculty of Agricultural Science, University San Raffaele, 00166 Rome, Itay; cristina.santini@uniroma5.it \\ * Correspondence: c.aleffi@unimc.it (C.A.); s.tomasi@unimc.it (S.T.)
}

Received: 30 June 2020; Accepted: 17 August 2020; Published: 27 August 2020

\begin{abstract}
This exploratory study focuses on the role of the university in supporting sustainable development in rural areas, focusing on small wine producers, particularly those located in remote and disadvantaged areas. Disadvantaged areas have distinctive features. Firstly, they are fragile areas from a sociodemographic point of view because of population ageing. Secondly, they are unstable from an environmental (physical, eco-systemic) point of view, as a consequence of insufficient maintenance of their seminatural capital. University-business cooperation with companies located in those areas thus needs to be designed by considering the specific characteristic of the place. Therefore, this exploratory study sought to understand how the university can work with small wineries and support them and their rural area to face inequalities and low growth, and foster social innovation. We present a case study based on field research in Italy. The results-based on the analysis of 26 semistructured interviews with small wine producers-are discussed by exploring the potential form of cooperation between rural stakeholders and universities, beyond the concept of knowledge transfer. Conclusions highlight the need for the university to act as a facilitator of dialogue at a territorial level, as a first step toward to formulation of shared sustainable goals.
\end{abstract}

Keywords: small wineries; sustainable development; disadvantaged areas

\section{Introduction}

This exploratory study focuses on university-business cooperation in the wine sector. It explores the potential role of the university to support sustainable development in disadvantaged rural areas, through collaboration with small wine producers. Therefore, through a field research carried out in three regions of Italy, the study seeks to identify the most effective approach for the universities to support rural communities. Conclusions highlight that trust and relationships should be taken as a foundation for any strategy of the university cooperation with rural actors.

In the following chapters, theoretical backgrounds on the addressed topics are presented: the theoretical introduction reports on the relationship between sustainable development and the characteristics of disadvantaged rural areas; the policies addressing them; university-business cooperation in the field of wine, as played out so far; finally, the challenges of small wineries in disadvantaged locations.

\subsection{The Sustainable Development of Disadvantaged and Inner Areas}

In recent years, territorial, economic and social cohesion in European regions became one of the most significant challenges for regional policy and structural funds. As highlighted by Mikulic and 
Nagyszombaty [1], the main focus of these policies was the need to identify new innovation-driven models to promote regional development and economic growth. In this context, one of the outstanding European objectives is the reduction of territorial unbalances in disadvantaged areas [2,3].

The term "disadvantaged" is broad, and it includes different meanings according to the adopted perspective. In some cases, the word disadvantaged is a synonym for peripheral or marginal. A disadvantaged area is an area that, due to its peripheral location, its specific resources, or the emergence of unpredictable and unfavourable natural events, has a lower competitive advantage when compared to other areas.

Disadvantaged rural areas represent a dichotomy: on one hand, they show a fragility because of the ageing population and environmental instability (physical, ecosystemic). On the other, they represent significant basins of unexploited cultural social, artistic and ecological resources that could constitute a potential for economic, social and cultural development.

In 2012, the Italian Government launched the concept of disadvantaged areas with the NSIA (National Strategy for Inner Areas) to promote actions for local development [4]. The theoretical background that has inspired the idea of inner areas can be found in the urban-centric model that has regulated the social and economic development in Italy after World War II [5]. The progressive abandonment of population and economic activities-due to the remoteness from services and urban centres [4] - has created the urgency for a national intervention policy. In Italy, according to the data released by the European Network for Rural Development, inner areas cover the $60 \%$ of the entire country, hosting the $23 \%$ of the population [4].

After having individuated five main areas of intervention (land management and forests; local food products, renewable energy; natural and cultural heritage and traditional crafts and SMEs (Small and Medium Entreprises), local strategies are designed. As some scholars suggest [6], local actors' involvement represents the critical factor of success for the programme.

We can say that a sustainable approach in terms of attention to new generations' needs, and the future enhancement of human capital, defines the place-based perspective of NSIA [7]. Within this framework, the NSIA (henceforth also called the Strategy) pivots on eight main themes: "practices on defence and usage of cultural heritage; the relationship between product innovation and local cultural traditional products; access to land; ecosystem services and production and alternative management of energy; sustainable farming; prevention of seismic events, and active management of the territory; attraction of a new immigrant population; citizen participation" [8]. From an operational perspective, the Strategy foresees two dimensions: (1) preconditions for local development, providing an adequate supply of essential goods and services and (2) local development projects, acting directly on the territories. The areas of intervention include active protection of the territory/environmental sustainability; enhancement of the natural/cultural capital and tourism; improvement of agri-food systems; activation of renewable energy supply chains; know-how and craftsmanship [4].

The debate on the classification of rural areas as inner areas is still open: we can say that, by considering the criterion of the distance from the main service centres [4], rural areas could be included within the category of the inner areas. Yet, as some scholars observe (see among the others, [5]), sometimes the term "inner" is employed as a synonym of peripheral, distant from a centre. In this paper, we will specifically focus on rural, disadvantages inner areas.

Scholars have investigated social and economic development in both inner areas, and rural inner areas; some works have highlighted that inner areas contribute to economic inequality with an impact that varies across the macroregions of Italy [9].

On the other hand, some scholars underline that, despite the accelerating demographic crisis which has been affecting inner areas for decades, in these territories many signs of civil, entrepreneurial, administrative and cultural vitality are visible [4].

In the above-described scenario, it emerges the importance of a development plan.

Europe has recognised the importance of rural development since 1960: its approach has evolved, from a focus on food productivity and modernisation in the early Common Agricultural Policies 
(CAP), to the introduction of sustainability and environmental issues in the 1994 CAP [10-12]. In 2006, the OECD developed the "new rural paradigm" suggesting policymakers to invest in capacity building and endogenous rural development, therefore supporting relations among sectors and fields toward a multidisciplinary approach to territorial development $[13,14]$. However, working on the future programming period 2021-2027, the European Commission proposes nine new objectives for the next CAP, which include both the need of making rural territories competitive, but also sustainable so as to reach Agenda 2030 goals [15].

There is no doubt that the pursuit of sustainable development is pivotal for inner rural areas [16].

At the same time, sustainable development of rural areas is complex as it is related to many factors: from regional and national policies to personal motives and cultural openness to sustainability among farmers [15,17-20].

\subsection{Small Wineries}

The wine industry is highly competitive and companies, even the smallest ones, must face the challenges of globalisation; wineries must be capable of responding rapidly and adapting to emerging changes [18]. As a result of the economic crisis and new emerging consumer needs, wine companies, according to some authors, have shown a resilient attitude, changing or adapting their business strategies. This scenario overwhelmingly demonstrates the pivotal role covered by firms' resources, capabilities and organisational skills, as well as the ability to seize business opportunities [21]. Small wineries in particular must face certain problems [22], such as the management of inputs and resources in the limits of small-scale production; limited access to capital markets; a low bargaining power with regards to retailers and distributors; general difficulties when exporting products to foreign markets [23]. The situation becomes even more challenging for producers located in disadvantaged areas: as argued by Stephens and Partridge [19], rural, remote, and lagging regions usually lack agglomeration economies and other features conducive to overall growth.

As it emerges from the literature, location has an impact on the pursuit of competitive advantage. It can represent an asset for wine companies who can benefit from the "country of origin effect" [20], but it can also be a leverage for facilitating some business practices or behaviours; we refer, for example to the impact of location in the adoption of sustainable practices in the wine business [24]. Background research also shows that location influences the firm's capability to innovate [25].

Given the characteristics of rural, inner areas, the presence of endogenous business communities can represent a turning point to stimulate growth $[26,27]$. The benefits related to the presence of local businesses in rural areas are many. First, locally owned businesses may magnify their positive impact on the region's economy because of their attitude to prefer local inputs to relocation. Moreover, local entrepreneurship, mainly when organised as a business network, can provide a diversified economic system less reliant on global markets and dominant firms [19]. In this sense, wineries and winemakers operating in inner areas could play a central role in facing and overcoming disadvantages related to their localisation. The rural and agricultural dimension has positive implications, both in terms of added value and employment [8]. The added value of agricultural production, including wine production, in rural areas, depends on three main factors: the territorial vocation of the production, the traditional production techniques and the location of production processes in the same production areas contribute to the high quality of agricultural output in rural, inner areas. The coexistence of these three conditions makes the agricultural productions of these areas a tangible expression of rural local identity, with significant effects both in cultural (local food just like cultural heritage) and social (strengthening the sense of belonging of the community to the territory) terms. Also, in recent years, some forms of local planning combining market orientation, job creation and local biodiversity protection have emerged in inner areas [4]. The network represents a substantial opportunity in this sense. As highlighted by Senyard et al., [21] wine producers can work together in attempts to enforce standards for quality and authenticity of products and brand positively the region where they operate. 


\subsection{University-Business Cooperation}

Community approaches to solving urgent social and economic problems such as unemployment and low growth have long been discussed.

Inner rural areas must face many challenges, as we have previously outlined. The role of universities in the development of the rural regions has been highlighted by Green and Haines [22]. They underline that universities facilitate the interaction among residents and they help to foster a discussion upon topics of common interest.

The literature confirms the decisive role pursued by universities in the development of rural areas: successful regional innovative systems involve cooperation at the local level between businesses and knowledge organisations such as universities, colleges, training organisations, research and development (R\&D) institutes, technology transfer agencies, business associations and financial institutions [23]. Especially in less developed areas, a collaboration between businesses and knowledge organisations can help rural regions to address the needs of globalisation and the knowledge economy [28]. The involvement of universities is essential to have a complete picture of the rural territory. They can be useful to understand and enhance the cultural and social strengths of a place and to facilitate dialogue between local businesses [29]. This form of cooperation can be called university-business cooperation. Since the second half of the 20th century, the concept of university-business cooperation (UBC) has become an object of study for scientific research. Then, the "triple helix" approach [30] and its developments 'toward the fourth helix' [31], demonstrated the importance of cooperation among university, industry, government, and civil society, to generate innovation, giving the university a key player role within a territorial system. Despite these acknowledgements in the literature, the European Commission's report "Measuring the impact of university-business cooperation" [32] stated that "cooperation activities between businesses and universities in the field of education have a relatively low profile". Successful collaboration, as Galan-Muros and Davey [33] point out, requires the trust and commitment of universities.

In the above described collaborative process, it is essential to consider the factors that, at the regional and territorial level, facilitate or inhibit the creation of relations. According to Wilson [34], when establishing a collaboration between companies and universities, trust and know-how exchange are fundamental in the networking process. In any relational process, organisational, individual and institutional issues are important aspects to consider [34-36]. Therefore, a successful university-business cooperation is primarily based on interpersonal and inter-institutional trust. It also takes into account the "community" dimension [36,37] and promotes links among players to achieve a structured UBC [38].

In the wine business, the relationship between Universities and the Industry has been fruitful so far, although mostly as research transfer. Today research represents a source of intuitions for companies to face challenges, such as the emerging of phylloxera [39]. It is also a useful tool to develop innovative production and processing solutions for winemakers [40]; with specific regards to the implementation of sustainable practices in the wine business, the literature has shown the proactive role pursued by associations and educational institutions [41]. Part of this work refers to network and hub creation across actors involved in the exchange of innovation and knowledge, including farmers, producers, educational institutions, federations of wine producers, industry associations and regulatory bodies [42]. Clusters can also foster the diffusion of innovation, as Giuliani and Bell demonstrated in their 2005 study of a Chilean wine cluster.

From the literature, it emerges that the presence of a stable set of relationships among stakeholders can influence the degree of innovativeness of the local business; this partially explains differences among countries in terms of innovativeness [40]. Ratten [43] explored the role of ecoinnovation in the competitiveness of the Barossa Valley wine region and observed that clusters foster the exchange of knowledge, support innovation and promote sustainability: improving knowledge sharing within a network influences the birth of ecoinnovations [44]. Smith [45] contended that wineries do not innovate on their own but need to interact with other external partners. According to an empirical study on the Hungarian wine industry [46], external stakeholders positively influence the overall firms' 
performance. Alonso [47] demonstrated that collaborations among different wineries and organisations are essential means for sharing ideas and experiences, as well as creating a social environment that fosters cooperation, social integration and trust. However, according to the author, there is not a complete understanding of the benefits that can potentially emerge from collaborations. As a result, collaboration significantly depends on the development of the sector in the wine-growing regions.

Boosting the involvement of wineries and stakeholders can foster innovation [48] and can raise the awareness about sustainable development and economic wellbeing. These elements are crucial to reduce the risk of social exclusion in rural areas, in which wineries are located.

\section{Materials and Methods}

This exploratory research aimed to understand how collaboration among wineries in disadvantaged areas and universities could encourage sustainable development. To do so, field research activities-here reported-were carried out to identify both the state of the art of the sector, in terms of perceived challenges and prospective solutions as defined by winemakers, and the potential for cooperation, both with the university and other actors of the rural community. The research was carried out in the frame of The Wine Lab project, a European project addressed to explore university-business cooperation in the field of wine, explicitly addressing small producers located in remote and disadvantaged areas.

The Wine Lab (TWL) Project was a three-year European Project financed within the Erasmus+-Knowledge Alliances framework. The project involved many partners in Europe, and it represented the chance for universities involved to foster a culture of university-business collaboration among participants.

Data collection was based on semistructured interviews with representatives of 26 wineries located in three regions of Italy: Marche (16), Tuscany (8), and Aosta Valley (2). Data were collected from October 2017 to February 2018. Respondents were selected by the following three criteria: size, location and geographical project area.

All selected wineries are small and medium-size, and include family-business enterprises. All the interviewed wineries are located in disadvantaged areas/wineries characterised by heroic viticulture. (According to the Centre for Research, Studies, Safeguarding, Coordination and Valorisation for Mountain Viticulture (CERVIM), heroic viticulture refers to all those viticultural productions located in disadvantaged areas identified by the following parameters: slope of the land over $30 \%$; altitude over $500 \mathrm{~m}$ above sea level; viticultural systems on terraces and steps; viticulture of small islands.). Furthermore, the areas they are settled in, are "under the coverage" of The Wine Lab (TWL) project: Marche, Tuscany and Aosta Valley.

The selected method, that is the semistructured interview, allows the respondents to express their views as fully as possible. Flexibility in the design and refinement of interview guides and the actual conduct of interviews is probably the most crucial key to success [49]. According to Horton et al. [50], this type of interview makes it possible to assess the integrity of the answer, to explore the opinion further, and to understand the importance of the elements and their content. Our choice was supported by the emerging insights from Bregoli et al. [51]. The authors have investigated how wine tourism operators conceive wine, to determine to which extent stakeholders collaborate and share knowledge.

The analysis of wineries first identified the challenges of the sector from their point of view. Subsequently, it explored possible forms of cooperation with other stakeholders, with a focus on the university. Validation of the interview protocol was carried out in two phases: (a) internal to the research group, through researchers' triangulation; (b) by administering the interview to three owners of small wineries, who were members of the project consortium, and discuss the results together, according to their experience, so as to identify possible missed relevant dimensions. The following Table 1 shows the proposed questions: 
Table 1. Interview questions.

\begin{tabular}{|c|c|c|}
\hline Main Questions & Theoretical Framework & Supplementary Questions \\
\hline $\begin{array}{l}\text { Which are, in your opinion, the most } \\
\text { relevant difficulties for small wineries } \\
\text { located in disadvantaged areas? }\end{array}$ & $\begin{array}{l}\text { Green, G. P., Haines, A. [22]; Torjman, S.; } \\
\text { Leviten-Reid, E [23] }\end{array}$ & $\begin{array}{l}\text { Are difficulties related to staff? To the } \\
\text { access to the market? To lack of } \\
\text { infrastructures? Any other reasons? }\end{array}$ \\
\hline $\begin{array}{l}\text { What do you think would be helpful } \\
\text { for you/your company to improve } \\
\text { market performance? }\end{array}$ & $\begin{array}{l}\text { Castaldi, R. M.; Cholette, S.; April, F [18]; } \\
\text { Ratten [43] }\end{array}$ & $\begin{array}{l}\text { Which investment (resource can also be } \\
\text { time, not only financial) could help in } \\
\text { overcoming difficulties? }\end{array}$ \\
\hline Main Questions & Theoretical Framework & Supplementary Questions \\
\hline $\begin{array}{l}\text { Do you believe that cooperation } \\
\text { between university and enterprise is } \\
\text { relevant to improve the performance of } \\
\text { small wineries? }\end{array}$ & $\begin{array}{l}\text { Wilson, T. [34]; Paul, H. W. [39]; Aylward, } \\
\text { D.; Turpin, T. [40]; Santini, C.; Cavicchi, A.; } \\
\text { Casini, L. [41] }\end{array}$ & $\begin{array}{l}\text { How can the present situation be } \\
\text { improved? } \\
\text { Is there any form of cooperation between } \\
\text { HEIs and enterprises that you believe } \\
\text { could work and has not been exploited yet? }\end{array}$ \\
\hline $\begin{array}{l}\text { Do you believe that networking of } \\
\text { subjects at local and regional levels can } \\
\text { make a difference? }\end{array}$ & Alonso, A. D. [47]; Lorentzen, J. [48] & $\begin{array}{l}\text { In the example, what about tourism } \\
\text { providers? Associations? }\end{array}$ \\
\hline
\end{tabular}

The analysis was carried out by line-to-line coding, clustering of main issues, and creation of categories which supported positioning of wineries within the study context [52].

\section{Results}

Analysis of data was carried out around the two dimensions under investigation: the first addressed to understand the challenges of running a business in wine in disadvantaged areas, and the second to explore the potential of university-business and territorial cooperation, to draw inputs for future planning of the universities' action at the local level.

\subsection{Major Challenges for Wineries}

The entrepreneurs indicated bureaucracy as the main issue, especially all the documents, certifications and inspections they must deal with. Some representatives of wineries affirmed to struggle with the numerous, long, and tricky rules and procedures, in particular related to certifications, as the requirements are strict and the process expensive, especially for small businesses. Almost all respondents pointed out to the burden of bureaucracy as the main challenge; some examples follow:

Particularly in the organic sector, there is a double burden of bureaucracy, if the company is small, then the onus is very significant. (Winemaker from Marche)

The biggest problem for small companies is bureaucracy. (Winemaker from Tuscany)

Within this frame, a further challenge related to social sustainability was identified in the lack of trained and professional staff: companies stressed their difficulty finding employees able to work in cellars or in vineyards and who are willing to accept a short-term contract. It is necessary to invest in human resources, but the wineries lack the funding to do so.

It is hard to find occasional staff and also challenging to be compliant with the fiscal laws. (Winemaker from Marche)

Another disadvantageous factor for small wineries is the recruitment of staff. It is a seasonal work, generally concentrated between April and September; there is too much bureaucracy and a complicated system that makes us unable to hire anyone in such a situation. (Winemaker from Aosta Valley)

Another negative factor is the difficulty of hiring staff occasionally, due to the disappearance of "vouchers", a fast and easy Italian system for employing in the short term. The bureaucracy does not facilitate the companies in hiring, with its restrictions and additional costs in comparison to the past. (Winemaker from Aosta Valley) 
From the emerging insights, wineries can hardly access to human resources: the set of norms that regulates employment-and in some cases interviewees refer to seasonal jobs-makes the recruitment of skilled workers challenging, despite their availability.

A third challenge was identified in the disadvantaged location, both for production (e.g., technology available to deal with challenging yards) and transportation/market access (as lack of infrastructures):

My difficulties depend from the lack of infrastructures. (Winemaker from Tuscany)

Another big problem is for machines to work in these areas. They are not so easy to find, and if you find them, they probably are costly, as they are built only for a specific kind of soil and only for a particular area. (Winemaker from Tuscany)

Location also contributes to a lack of exchange, and community relations play a role. In the words of one winemaker:

By definition, wineries are located in the most challenging areas to reach. Poor quality roads and the lack of fast internet connection generate an "isolationist" attitude in farmers. The isolation of the land contributes to a sort of "absolutism of thought", and a weak capability to relate with others and to share and work in a team. (Winemaker from Marche)

A fourth challenge was identified in selling and promoting wine in the national and international market: the main issues concerned the difficulty of keeping long-lasting relationships with clients, understanding what consumers want and proposing products to foreign customers in an organised way.

In this moment it should be necessary to change the mindset of the traditional farmer. We need to invest in commercial issues. (Winemaker from Marche)

Another challenge was identified in the lack of cooperation among companies:

In our region, it is tough to create relationships among entrepreneurs. It would be important that someone, like the University, create a link among all the companies in the territory. (Winemaker from Marche)

Here there is no cooperation among companies. (Winemaker from Marche)

We are not really able to cooperate, we never wholly accomplish anything, everything is left to volunteerism. (Winemaker from Marche)

We do not have any relations with other companies, as they do not share our approach toward organic and natural products. (Winemaker from Marche)

However, while acknowledging present difficulties, networking is positively evaluated from a business point of view-among wine producers, but also with other companies and stakeholders, particularly tourism:

Networking is the key to success: less effort, lower costs, greater efficiencies, and effective results. This last aspect means the capacity for the company to have cash flow resources for economic reinvestment. (Winemaker from Marche)

It would be helpful to come together as wineries to have more funds because one winery on its own cannot afford the expensive costs of international events. (Winemaker from Tuscany)

At the local level, networking is useful for producers to get lower costs both at the production and at the commercial level. Even at the political level, it gains more strength. (Winemaker from Aosta Valley) 
Of course, it is important to create networks, as we have already begun to do in our area. That could allow small companies to have more strength and visibility for also attracting the importers. (Winemaker from Aosta Valley)

I think that an association composed by wine producers and the creation of permanent stores managed by the association would be helpful. (Winemaker from Tuscany)

I believe that it is fundamental to know your own cultural identity and the tradition of your territory by transferring them into the value of the wine produced. In this way, you can share this value with tourists by involving them in your history. Surely, collaboration with cultural associations is essential, so people, especially tourists, are more enthusiastic about the territory, and they are also keen to taste their products. (Winemaker from Aosta Valley)

I think that joint initiatives with tour operators could be helpful. (Winemaker from Tuscany)

We need to work on raising awareness of the typical character of the territory. (Winemaker from Marche)

\subsection{Potential of University-Business Cooperation}

As what concerns possible forms of collaboration between universities and enterprises to foster innovation and sustainability, respondents were positive in general terms, but also stressed some critical points:

It could help, but it wouldn't make any difference. (Winemaker from Tuscany)

We have a too tight bond with the land; therefore we have little time to implement other projects. (Winemaker from Tuscany)

One of the winery representatives explained that they had a negative experience with a university, but are willing to give this vision a second chance. (Winemaker from Marche)

We have already tried to cooperate with a university located in the region, but it was unsuccessful, and did not have any added value for the company. It always depends on people and objectives; I am still hopeful and available. (Winemaker from Marche)

Asked about their perception of graduates' skills, and the willingness to cooperate with the university also through students' mobility (internships or placements), winemakers expressed a general openness, with some concerns:

I have never had experiences with internships with universities, I have had experiences, especially with agricultural high school students ... maybe an agronomist might be suitable for this experience because my small company is more focused on manual work. (Winemaker from Marche)

I believe that university and business cooperation helps improve the preparation of students by bringing them closer to the practical part. In turn, they can bring novelties and new techniques to the company in which they operate. [ ... ] When I was studying, I was the first person to benefit from that opportunity, and that kind of experience helped me expand my knowledge and test at a practical level what my future job would have been. (Winemaker from Aosta Valley)

I believe that this is not the case of small companies (referring to internships). (Winemaker from Tuscany) 
Well, to work in my winery it is more necessary to have a practical approach than a scientific approach. (Winemaker from Tuscany)

We are open to internships ... but the timing should be planned before the beginning: little companies have little time to devote to students' training. Also, the work programme for the student must be already fixed before their arrival. (Winemaker from Marche)

Most essential skills, for those who consider the idea of hosting an intern, or hire a graduate are marketing and selling, to which technology is added as a promising channel to enlarge the market:

Thinking about my company, you need to have an education also for what concerns technologies. (Winemaker from Tuscany)

It is important to know the winery to understand production, transformation and marketing. Students need to know everything from production and so the "making of "the wine to sell it. (Winemaker from Tuscany)

New graduates could bring some knowledge about computer science and the use of social networks that are nowadays part of everyday use and not everyone knows how to use them with familiarity. Those elements would create added value that could help them to be present on other market types such as the online one. (Winemaker from Aosta Valley)

Critical points have been stressed about preparation and attitude:

Expectations are too different. (Winemaker from Marche)

Graduates have an exaggerated technical knowledge, at the expense of practical experience and natural agriculture. (Winemaker from Marche)

Graduates/students lack humility and have little practical experience. They fear new experiences. (Winemaker from Marche)

They lack practical experience, and they also lack willingness (of doing) ... it seems that they don't want to enter the labour market. (Winemaker from Marche)

\section{Discussion and Conclusions}

The exploratory research was carried out to understand how the university can work with small wineries and support them and their rural area to face inequalities and low growth, and foster social innovation. Assumptions, as retrieved from background research, included conditional factors of small wineries as small companies, and characteristics of rural areas in terms of cultural identity and awareness of system-level challenges, which influence both business performance and prospective development.

Field research shows a greater focus on the business dimension rather than on the rural dimension in terms of opportunities: winemakers recognised the relevance of cooperation at a territorial level for increasing sale and profit; however, they failed to recognise the value of the area in terms of 'branding' for business. They estimated networking as a way to reciprocal help, which is a traditional trait of rural communities, or as a means to have more bargaining power or selling opportunities, as any other company, regardless of location.

We should also underline that, in all the considered areas, there is a strong presence of associations, of local producers and operators. This is a critical element to emphasise, since it helps to understand what the people interviewed seek when they talk about a lack of cooperation. What emerges is that, behind the opportunities of collaborations offered by formal and established stakeholder networks, small winemakers in rural, inner areas seek cooperative networks able not only to nurture interpersonal relations but also to provide solutions to specific problems. 
To support the above consideration, from the interviews it emerges the awareness of networking with tourism organisations: respondents see them as a leverage to increase wine sales. The need for networking for local development as a key element to allow the consequent increase of wellbeing, also in business terms, was instead not mentioned.

In general, from the interview it emerges a positive perception of cooperation: interviewed wineries do not doubt that cooperation can be fruitful, but as one respondent has declared, it is hard to understand where the added value stands. The feeling emerging from the analysis is that wineries perceive the urgency of keeping a problem-solving orientation when establishing their collaborative networks.

Furthermore, there was a general complaint about laws and the burden of bureaucratic duties, as well as about the lack of infrastructures. However, none of the interviewees considered the possibility of taking an active role to face the problem. As a confirmation of this, networking, joint actions both with other companies and stakeholders of civil society, and dialogue with policymakers were not mentioned to this respect.

The same attitude was retrieved in relation to the university: in general, there was a positive evaluation toward a potential cooperation with universities, with few exceptions. However, when prompted with specific questions about possible forms of collaboration, e.g., internships, they referred almost exclusively to agriculture. Even respondents who approached students in marketing and business, stressed the importance of knowing the production, in order to be able to communicate (sell) the product appropriately. Several interviewees also reported negative opinions about graduates and youths, perceived as too theoretical and lacking practical experience.

In general, the data show a widespread lack of system-thinking: connections of the companies either with other companies or different stakeholders (including educational institutions, policymakers, civil society) are neither strong nor pursued. Whether there is some input concerning the rural dimension, it is perceived concerning environmental and identity values. Winemakers seem instead to fail to recognise the added value of the social dimension of rural development, which includes health, care, schooling, accessibility, and all which is not directly linked with business.

There is a single word that summarises all the challenges that small wineries in inner disadvantaged rural areas perceive: accessibility.

From the interviews, it emerges that wineries complain about the degree of accessibility of their location, about how difficult is it for them to access to funding, resources, skilled workers, or innovative solutions (in particular they have mentioned problems for getting tailored designed equipment for their production process).

Respondents refer to bureaucracy as one of the main inhibitors of superior performance in their activities. Since bureaucracy is an element that has been introduced by someone else than wine producers, it is easy to understand why they attribute the responsibility of its management to third parties: the reluctance in finding a solution to the problem of bureaucracy depends on the perception that respondents have of norms and obstacles to resource accessibility.

Results of the data analysis are not surprising: challenges of small wineries located in disadvantaged areas are indeed remarkable: most of them fight for survival. Consequently, they tend to have a short-term view of development. Sustainable development, however, is based on a long-term perspective.

From what emerges from the interviews, we can say that the perception of operating in an environment with an overall low degree of accessibility impacts the understanding of wineries' role in sustainable development. Wineries perceive some barriers that inhibit their willingness to innovate (it is hard for them to access to tailored, innovative solutions, or to hire skilled and talented workforce), to collaborate (it is hard for them to recognise where the added value stands in UBCs), to establish a dialogue with local governments (the issue of bureaucracy is a recurring issue in the interviews). 
Given the above-described scenario, in order to be fruitful, UBCs should focus on two issues: to adopt a problem-solving orientation in the dialogue between academicians and practitioners and to foster sustainable development.

For what concerns the problem-solving orientation, from this case it emerges that a participative approach is particularly useful. The experience of TWL, in this sense, has represented a successful example: the project has contributed to the creation of local wine hubs who have promoted a dialogue among participants to assess the specific needs of wineries. Through creative and participatory processes-following the format of hackathons, for example—solutions have been designed to address production or marketing problems. This has represented a step ahead from the general compliant and a help for wineries to identify how UBCs can add value to a relationship.

However, to support the process toward sustainable development in rural areas, universities can count on some strengths:

- Rural areas have stronger community links: this characteristic could not be applied to the individual as 'entrepreneur', but it is certainly applied to the individual as a citizen, the inhabitant of the place;

- Rural communities have a stronger sense of belonging to the place, and they care for the place;

- The sense of 'risk' (of bankruptcy, of poverty) is high in rural entrepreneurs, as they face their weaknesses as small companies in a global world, and they see disadvantages of 'being rural' (accessibility, lack of infrastructure, higher costs);

- Above all, winemakers recognise their need of 'doing something', even if from interviews none of them seemed to see which could be this form of 'doing' (some mentioned 'tourism', others 'becoming more commercial').

By taking the pivots of the Italian Strategy for Inner areas as a level of analysis, we argue that winemakers contribute to most of them through social innovation concerning the three dimensions of sustainable development:

- Economic sustainability (pivots: practices on defence and usage of cultural heritage; the relationship between product innovation and local cultural traditional products): network with other stakeholders, mainly those active in rural tourism, can increase business opportunities and employment rates. Recent tourism trends show an increased interest for experiential and relational tourism experiences, in which cultural heritage, tradition and identity play a significant role.

- Environmental sustainability (pivots: access to land; ecosystem services, and production and alternative management of energy; sustainable farming; prevention of seismic events, and active management of the territory): environmental awareness is higher in winemakers than on the average of the population; they live with and through the land, and they respect the land. Further, they manage and take care of inner areas otherwise abandoned. In Italy, a country characterised by high territorial fragility, this is particularly important. Finally, the fact that winemakers live in disadvantaged areas-coupled with potential economic and social implications here described-can also contribute to an improved access to land, which is pursued when people inhabit the place.

- Social sustainability (pivots: attraction of a new immigrant population; citizen participation): in particular economic sustainability can contribute to social sustainability, as employment is a remarkable attractive aspect of any place. Moreover, through networking in the frame of social innovation processes, citizens' participation naturally increases and generates additional value in all of the three pillars.

On the basis of the identified potentialities, universities have the opportunity to act as facilitators of dialogue at a territorial level to promote social innovation, with the following objectives:

- Increase reciprocal understanding of different community groups, supporting the sense of belonging to a community and overcoming the sense of isolation; 
- Increase awareness of the relevance of system-thinking, supporting the understanding of connections between economic, environmental and social instances;

- Foster collaboration among different stakeholders, either in terms of business relations or social relations;

- Support links with policymakers and the rural community, therefore grounded and effective policy planning;

- Bring new knowledge into the discussion, to stimulate reflection on possible opportunities.

In other terms, the university can support processes of cocreation of sustainable practices [53] by winemakers and farmers, through and for the community. However, preliminary actions of stakeholder engagement through networking would be required, so as to render the idea that 'rural life' has a comprehensive meaning understandable and common, and goals should be shared across community groups. Universities located in rural areas should be "equals among equals", and as such should be recognised to foster mutual trust: this means that, like other actors, they offer their capacities and competencies to reach sustainable goals. Therefore, universities could at least provide knowledge; global thinking applied in regional contexts, educated youths, which should be included in the developmental process, and a long-term vision that is usually missing at the local level. In this way, they can support sustainable development in rural areas, contributing to diminishing inequality and low growth through social innovation processes.

Author Contributions: Conceptualisation: A.C.; data collection: F.B.; chapters writing: Section 1.1. The Sustainable Development of Disadvantaged and Inner Areas: C.F.; Section 1.2. Small wineries: C.S.; Section 1.3. University business cooperation: C.A.; Materials and Methods: G.P.; Results: S.T.; and Discussion and conclusions: C.A. All authors have read and agreed to the published version of the manuscript.

Funding: The European Commission funded this research through the Erasmus+ programme Knowledge Alliances-The Wine Lab, project number 575782-EPP-1-2016-1-IT-EPPKA2-KA, agreement number 20163193.

Conflicts of Interest: The authors declare no conflict of interest.

\section{References}

1. Mikulić, D.; Nagyszombaty, A.G. Does International Trade Cause Regional Growth Differentials in Croatia? Zb. Rad. Ekon. Fak. Rijeci časopis Ekon. Teor. Praksu 2015, 33, 81-102.

2. European Commission. Territorial Agenda of the European Union 2020: Towards an Inclusive, Smart and Sustainable Europe of Diverse Regions. In Proceedings of the Informal Ministerial Meeting of Ministers Responsible for Spatial Planning and Territorial Development, Gödöllő, Hungary, 19 May 2011.

3. Antonescu, D. New Cohesion and Regional Policy in 2021-2027 Period. MPRA Pap. 2020, 98122.

4. Barca, F.; Casavola, P.L.S. A Strategy for Inner Areas in Italy: Definitions, Objectives, Tools and Governance. Mater. Uval Ser. 2014, 31, 1-62.

5. Bertolini, P.; Pagliacci, F. Quality of Life and Territorial Imbalances. A Focus on Italian Inner and Rural Areas. Bio-based Appl. Econ. 2017, 6, 183-208. [CrossRef]

6. Salvatore, R.; Chiodo, E.; Fantini, A. Tourism Transition in Peripheral Rural Areas: Theories, Issues and Strategies. Ann. Tour. Res. 2018, 68, 41-51. [CrossRef]

7. Carrosio, G. A Place-Based Perspective for Welfare Recalibration in the Italian Inner Peripheries: The Case of the Italian Strategy for Inner Areas. Sociol. E Polit. Soc. 2016, 3, 50-64. [CrossRef]

8. Basile, G.; Cavallo, A. Rural Identity, Authenticity, and Sustainability in Italian Inner Areas. Sustainability 2020, 12, 1272. [CrossRef]

9. Giovanni, G.; Francesco, P. Widening the Gap: The Influence of Inner Areas in the Income Inequality in Italy. Econ. Polit. 2019, 37, 197-211.

10. Wilson, G.A. From Productivism to Post-Productivism and Back Again? Exploring the (Un)Changed Natural and Mental Landscapes of European Agriculture. Trans. Inst. Br. Geogr. 2001, 26, 77-102. [CrossRef]

11. Knickel, K. Agricultural Structural Change: Impact on the Rural Environment. J. Rural Stud. 1990, 6, 383-393. [CrossRef] 
12. Messely, L. On Regions and Their Actors: An Analysis of the Role of Actors and Policy in Region-Specific Rural Development Processes in Flanders. Ph.D. Thesis, Ghent University, Ghent, Belgium, 2014.

13. Ambrosio-Albalá, M.; Bastiaensen, J. The New Territorial Paradigm of Rural Development: Theoretical Foundations from Systems and Institutional Theories. IOB Discuss. Pap. 2010, 2, 1-69.

14. Cairol, D.; Coudel, E.; Barthélémy, D.; Caron, P.; Cudlinova, E.; Zander, P.; Renting, H.; Sumelius, J.; Knikel, K. Multifunctionality of Agriculture and Rural Areas: From Trade Negotiations to Contributing to Sustainable Development: New Challenges for Research. Int. J. Agric. Resour. Gov. Ecol. 2008, 7, 4-5.

15. European Commission. CAP Strategic Plans-Proposal for a Regulation COM(2018) 392; European Commission: Brussels, Belgium, 2018.

16. Aleffi, C.; Cavicchi, A. The Role of Food and Culinary Heritage For Postdisaster Recovery: The Case of Earthquake in the Marche Region (Italy). J. Gastron. Tour. 2020, 4, 113-128. [CrossRef]

17. Eurostat. Vineyards in the EU-Statistics. Available online: https://ec.europa.eu/eurostat/statistics-explained (accessed on 24 August 2020).

18. Castaldi, R.M.; Cholette, S.; April, F. Globalization and the emergence of new business models in the wine industry. Int. Bus. Econ. Res. J. 2005, 4, 3. [CrossRef]

19. Stephens, H.M.; Partridge, M.D. Do Entrepreneurs Enhance Economic Growth in Lagging Regions? Growth Chang. 2011, 42, 431-465. [CrossRef]

20. Felzensztein, C.; Hibbert, S.; Vong, G. Is the Country of Origin the Fifth Element in the Marketing Mix of Imported Wine? A Critical Review of the Literature. J. Food Prod. Mark. 2004, 10, 73-84. [CrossRef]

21. Senyard, J.M.; Smith, E.; Baker, T.; Steffens, P.R.; Davidsson, P. Stop Whining and Make the Best of It: A Cross-National Comparison of Responses to Regional Disadvantage in the Wine Industry. In Proceedings of the 2012 Australian Centre for Entrepreneurship Research and DIANA Conference (ACERE DIANA), Fremantle, Australia, 3-5 February 2012.

22. Green, G.P.; Haines, A. Asset Building and Community Development; Sage Publications Ltd.: Thousand Oaks, CA, USA, 2015.

23. Torjman, S.; Leviten-Reid, E. Innovation and Poverty Reduction; The Caledon Institute of Social Policy: Ottawa, ON, Canada, 2003.

24. Gilinsky, A.; Newton, S.K.; Atki, T.S.; Santini, C.; Cavicchi, A.; Casas, A.R.; Huertas, R. Perceived Efficacy of Sustainability Strategies in the US, Italian, and Spanish Wine Industries. Int. J. Wine Bus. Res. 2015, 27, 164-181. [CrossRef]

25. Gilinsky, A.; Santini, C.; Lazzeretti, L.; Eyler, R. Desperately Seeking Serendipity: Exploring the Impact of Country Location on Innovation in the Wine Industry. Int. J. Wine Bus. Res. 2008, 20, 302-320. [CrossRef]

26. Deller, S.; McConnon, J.C. Microenterprises and Economic Growth: A Panel Study of the US States 1977-1997. Appl. Econ. Lett. 2009, 16, 1307-1312. [CrossRef]

27. Goetz, S.J.; Rupasingha, A. Determinants of Growth in Non-Farm Proprietor Densities in the US, 1990-2000. Small Bus. Econ. 2009, 32, 425-438. [CrossRef]

28. Rinaldi, C.; Cavicchi, A. Universities' Emerging Roles to Co-Create Sustainable Innovation Paths: Some Evidences from the Marche Region. Aestimum 2016, 69, 211-224. [CrossRef]

29. Rinaldi, C.; CavicchI, A.; Corsi, M. Sustainable Tourism in Rural Areas: The Role of Higher Education in the Marche Region. In Proceedings of the Association of Tourism in Higher Education Annual Conference 2010 "Restating the Case for Tourism in Higher Education", Canterbury, UK, 1-3 December 2010; McCabe, S., Gale, T., Eds.; Association for Tourism in Higher Education (ATHE): Polegate, UK, 2011; pp. 161-178.

30. Etzkowitz, H. The Triple Helix: University-Industry-Government Innovation in Action; Routledge Taylor \& Francis Group: New York, NY, USA, 2008. [CrossRef]

31. Ranga, M.; Etzkowitz, H. Triple Helix Systems: An Analytical Framework for Innovation Policy and Practice in the Knowledge Society. Ind. High. Educ. 2013, 27, 237-262. [CrossRef]

32. Goddard, J.; Healy, A.; Perkmann, M.; Kempton, L. Measuring the Impact of University-Business Cooperation: Case Studies; Publications Office of the European Union: Luxembourg, 2015.

33. Galan-Muros, V.; Davey, T. The UBC Ecosystem: Putting Together a Comprehensive Framework for University-Business Cooperation. J. Technol. Transf. 2019, 44, 1311-1346. [CrossRef]

34. Wilson, T. A Review of Business-University Collaboration; Department for Business, Innovation and Skills: London, UK, 2012. 
35. Phan, P.H.; Siegel, D.S. The Effectiveness of University Technology Transfer. Found. Trends Entrep. 2006, 2, 77-144. [CrossRef]

36. Rinaldi, C.; Cavicchi, A.; Spigarelli, F.; Lacchè, L.; Rubens, A. Universities and Smart Specialisation Strategy: From Third Mission to Sustainable Development Co-Creation. Int. J. Sustain. High. Educ. 2018, 19, 67-84. [CrossRef]

37. Hakanen, M. The Development and Management of Interpersonal Trust in a Business Network in Health, Exercise, and Wellbeing Markets; University of Jyväskylä: Hueskille, Finland, 2017; ISBN 978-951-39-6996-7.

38. Aleffi, C.; Paviotti, G.; Tomasi, S.; Ferrara, C.; Cavicchi, A. Research, Education and Co-Creation: The University in Place. Capitale Cult. 2020, 11, 108-117.

39. Paul, H.W. Science, Vine and Wine in Modern France; Cambridge University Press: Cambridge, UK, 1996. [CrossRef]

40. Aylward, D.; Turpin, T. New Wine in Old Bottles: A Case Study of Innovation Territories in "New World" Wine Production. Fac. Int. J. Innov. Manag. 2003, 7, 501-525. [CrossRef]

41. Santini, C.; Cavicchi, A.; Casini, L. Sustainability in the Wine Industry: Key Questions and Research Trends. Agric. Food Econ. 2013, 1, 9. [CrossRef]

42. Dana, L.P.; Winstone, K.E. Wine Cluster Formation in New Zealand: Operation, Evolution and Impact. Int. J. Food Sci. Technol. 2008, 43, 2177-2190. [CrossRef]

43. Ratten, V. Eco-Innovation and Competitiveness in the Barossa Valley Wine Region. Compet. Rev. 2018, 28, 318-331. [CrossRef]

44. Cainelli, G.; Mazzanti, M.; Montresor, S. Environmental Innovations, Local Networks and Internationalization. Ind. Innov. 2012, 19, 697-734. [CrossRef]

45. Smith, K. Technological and Economic Dynamics of the World Wine Industry: An Introduction. Int. J. Technol. Glob. 2007, 3, 127-137. [CrossRef]

46. Dries, L.; Pascucci, S.; Török, Á.; Tóth, J. Open Innovation: A Case-Study of the Hungarian Wine Sector. EuroChoices 2013, 12, 53-59. [CrossRef]

47. Alonso, A.D. "Standing Alone You Can't Win Anything": The Importance of Collaborative Relationships for Wineries Producing Muscadine Wines. J. Wine Res. 2011, 22, 43-55. [CrossRef]

48. Lorentzen, J. Knowledge, Science and Interactions in South Africa's Wine Industry. In Innovation and Technological Catch-Up The Changing Geography of Wine Production; Elisa, G., Andrea, M., Rabellotti, R., Eds.; Edward Elgar Publishing: Chautam, UK, 2011. [CrossRef]

49. Yin, R.K. Case Study Research Design and Methods, 2nd ed.; Sage Publications Inc.: Thousand Oaks, CA, USA, 1994.

50. Horton, J.; Macve, R.; Struyven, G. Qualitative Research: Experiences in Using Semi-Structured Interviews. In The Real Life Guide to Accounting Research A Behind-The-Scenes View of Using Qualitative Research Methods; Elsevier: Amsterdam, The Netherlands, 2004; pp. 339-357. [CrossRef]

51. Bregoli, I.; Hingley, M.; Del Chiappa, G.; Sodano, V. Challenges in Italian Wine Routes: Managing Stakeholder Networks. Qual. Mark. Res. Int. J. 2016, 19, 204-224. [CrossRef]

52. Charmaz, K. Constructing Grounded Theory, 2nd ed.; Sage Publications Ltd.: Sauzenda Oakes, CA, USA, 2014.

53. Cavicchi, A.; Rinaldi, C.; Corsi, M. Higher Education Institutions as Managers of Wicked Problems: Place Branding and Rural Development in Marche Region, Italy. Int. Food Agribus. Manag. Rev. 2013, 16, 51-68.

(C) 2020 by the authors. Licensee MDPI, Basel, Switzerland. This article is an open access article distributed under the terms and conditions of the Creative Commons Attribution (CC BY) license (http://creativecommons.org/licenses/by/4.0/). 